\title{
Kribbella lupini sp. nov., isolated from the roots of Lupinus angustifolius
}

\author{
Martha E. Trujillo, ${ }^{1}$ Reiner M. Kroppenstedt, ${ }^{2}$ Peter Schumann ${ }^{2}$ \\ and Eustoquio Martínez-Molina ${ }^{1}$ \\ ${ }^{1}$ Departamento de Microbiología y Genética, Edificio Departamental, Lab. 209, Campus Miguel \\ de Unamuno, Universidad de Salamanca, 37007 Salamanca, Spain \\ ${ }^{2}$ DSMZ-Deutsche Sammlung von Mikroorganismen und Zellkulturen GmbH, Mascheroder Weg \\ 1b, 38124 Braunschweig, Germany
}

Correspondence

Martha E. Trujillo

mett@usal.es
The genus Kribbella (Park et al., 1999) includes six species that form a homogeneous group within the family Nocardioidaceae. While most Kribbella species have been isolated from soil, the recent description of Kribbella solani (Song et al., 2004) recovered from potato tubers suggests that soil is not the only ecological niche where these bacteria may be found. In the present paper, we report on the isolation of a novel actinomycete strain, LU14 ${ }^{\mathrm{T}}$, from the root nodules of Lupinus angustifolius, a native plant from the Mediterranean.

Strain $\mathrm{LU} 14^{\mathrm{T}}$ was isolated from root nodules of $L$. angustifolius growing near a former uranium mine in Salamanca, Spain. The root samples were washed twice with sterile distilled water and surface sterilized using $\mathrm{HgCl}_{2}$ $(1 \%, \mathrm{w} / \mathrm{v})$ for $2 \mathrm{~min}$. The samples were rinsed five times with sterile distilled water and crushed using a sterile glass rod. The macerate was inoculated on yeast extract-mannitol agar (Vincent, 1970) and the plates were incubated for 3 weeks at $28{ }^{\circ} \mathrm{C}$. Mycelium formation, colony colour and other growth characteristics were examined for 3 weeks on various culture media including SA1 (Trujillo et al., 2005), ISP 2 (Shirling \& Gottlieb, 1966) and nutrient agar.

Published online ahead of print on 25 November 2005 as DOI 10.1099/ijs.0.63745-0.

Abbreviation: LL-Dpm, LL-diaminopimelic acid.

The GenBank/EMBL/DDBJ accession number for the 16S rRNA gene sequence of Kribbella lupini sp. nov. strain LU14 ${ }^{\top}$ is AJ811962.

A supplementary table detailing cellular fatty acid profiles for strain LU14 ${ }^{\top}$ and Kribbella sandramycini is available in IJSEM Online.
Gram- and acid-fast-staining procedures were performed on 3 day cultures (Doetsch, 1981).

For chemotaxonomic analyses, strain $\mathrm{LU} 14^{\mathrm{T}}$ was grown in tryptic soy broth in flasks on a rotary shaker at 90 r.p.m. and $28^{\circ} \mathrm{C}$. Biomass was harvested, washed in distilled water and freeze-dried. Cell walls were prepared according to the method of Schleifer (1985). Peptidoglycan structure was studied in whole- and partial-cell-wall hydrolysates using TLC on cellulose (Schleifer \& Kandler, 1972). Analysis of sugars in the purified cell walls was carried out as described by Staneck \& Roberts (1974). Menaquinones were extracted and purified by the method of Minnikin et al. (1984) and analysed by HPLC (1100; Hewlett Packard). Methyl esters of cellular fatty acids for $\mathrm{LU}_{1} 4^{\mathrm{T}}$ and Kribbella sandramycini DSM $15626^{\mathrm{T}}$ were prepared from cells grown for $24 \mathrm{~h}$ on trypticase soy agar cultures $\left(28^{\circ} \mathrm{C}\right)$ and analysed by GLC (Schröeder et al., 1997). Polar lipids were extracted and identified by two-dimensional TLC (Minnikin et al., 1984).

Catalase activity was determined by observing bubble formation in a culture after the addition of $3 \%$ hydrogen peroxide. Oxidase activity was determined by oxidation of $1 \%$ tetramethyl- $p$-phenylenediamine. Hydrolysis of arbutin, aesculin, starch, tyrosine and xylan was determined according to Trujillo et al. (2005). Tests for the utilization of various substrates as sole carbon and energy sources were performed as described by Williams et al. (1983). Antibiotic resistance was examined as described by Trujillo et al. (2005). Determination of temperature and $\mathrm{pH}$ growth rates and tolerance of $\mathrm{NaCl}$ were performed on nutrient agar. 
Strain LUP $14^{\mathrm{T}}$ was also characterized using miniaturized API 20NE, API Coryne and API ZYM tests (bioMérieux) following the manufacturer's instructions. The reference strains Kribbella antibiotica DSM $15501^{\mathrm{T}}$, Kribbella flavida KACC $20248^{\mathrm{T}}$, Kribbella koreensis IMSNU $50530^{\mathrm{T}}$ and $K$. sandramycini DSM $15626^{\mathrm{T}}$ were also included in the physiological studies for comparison.

Genomic DNA extraction, PCR amplification of the $16 \mathrm{~S}$ rRNA gene and sequencing parameters were as described previously (Rivas et al., 2003). An almost-complete sequence was obtained and aligned against members of the family Nocardioidaceae using CLUSTAL_X (Thompson et al., 1997). A phylogenetic tree was constructed according to the neighbour-joining method (Saitou \& Nei, 1987) using the Kimura two-parameter distance matrix and compared with an additional tree obtained using the maximum-parsimony method (Fitch, 1971). In both cases, 1000 resamplings were used for bootstrap analysis. All analyses were carried out with the MEGA2 program (Kumar et al., 2001).

Genomic DNA for hybridization studies was isolated using a French pressure cell (Thermo Spectronic) and purified by chromatography on hydroxyapatite as described by Cashion et al. (1977). DNA-DNA hybridization [in $2 \times$ SSC plus $10 \%(\mathrm{v} / \mathrm{v}) \mathrm{DMSO}$ at $67^{\circ} \mathrm{C}$ ] was performed between strain $\mathrm{LU} 14^{\mathrm{T}}$ and its closest neighbour, $K$. sandramycini DSM $15626^{\mathrm{T}}$, as described by De Ley et al. (1970) and modified by Huß et al. (1983), using a Cary 100 Bio UV/VISspectrophotometer (Varian). The DNA G $+\mathrm{C}$ content was determined using the thermal melting method (Mandel \& Marmur, 1968).

On all media tested, colonies were white to cream coloured with a pasty texture and lichenous shapes. No diffusible pigments were observed on any of the media. Substrate mycelium was extensively branched and penetrated into the agar and fragmented into rods; white aerial mycelium was produced abundantly and fragmented into non-motile rods.

A $16 \mathrm{~S}$ rRNA gene sequence of $1458 \mathrm{nt}$ was obtained for isolate $\mathrm{LU} 14^{\mathrm{T}}$. The results of the phylogenetic analysis (Fig. 1) revealed that the isolate formed a separate line of descent in the phylogenetic cluster of the genus Kribbella. The closest neighbour of strain LU14 ${ }^{\mathrm{T}}$ was K. sandramycini
KACC $20249^{\mathrm{T}}$, with $98 \cdot 7 \%$ 16S rRNA gene sequence similarity, followed by K. flavida NBRC $14399^{\mathrm{T}}$ with $98 \cdot 6 \%$ similarity. The sequence similarities with other species of the genus were in the range $98 \cdot 2-97 \cdot 1 \%$. A very similar tree was obtained using the maximum-parsimony method (data not shown).

Overall, the chemotaxonomic markers found are in agreement with the affiliation of strain $\mathrm{LU} 14^{\mathrm{T}}$ to the genus Kribbella. The total hydrolysate of the cell-wall peptidoglycan contained LL-diaminopimelic acid (LL-Dpm), glycine, glutamic acid and alanine; the partial hydrolysate contained the peptides L-Ala-D-Glu, LL-Dpm-D-Ala and LLDpm-Gly, which corresponded to type A3 $\gamma$ peptidoglycan (Schleifer \& Kandler, 1972). Galactose and one unidentified component, which is neither arabinose, glucose, mannose, rhamnose, ribose nor xylose, were detected in the purified cell wall of isolate $\mathrm{LU} 14^{\mathrm{T}}$. Galactose was also reported in the whole cell sugar patterns of the remaining recognized Kribella species (Song et al., 2004; Li et al., 2004), with the exception of K. antibiotica DSM $15501^{\mathrm{T}}$ (Li et al., 2004), which contains glucose, ribose and xylose. In the case of K. sandramycini KCTC $9609^{\mathrm{T}}$ and K. flavida KACC $20248^{\mathrm{T}}$, glucose, mannose and galactose were reported (Li et al., 2004), while these three sugars and ribose were found in K. koreensis IMSNU $50530^{\mathrm{T}}$, Kribbella jejuensis JCM $12204^{\mathrm{T}}$ and Kribbella solani JCM $12205^{\mathrm{T}}$. These data suggest that the cell-wall sugar composition can be used as an important marker to differentiate species of the genus Kribbella.

The main menaquinones found were MK-9 $\left(\mathrm{H}_{4}\right)$ (93\%) and MK- $9\left(\mathrm{H}_{2}\right)(7 \%)$. The fatty acid profiles of strain LU14 ${ }^{\mathrm{T}}$ and its closest phylogenetic neighbour, $K$. sandramycini DSM $15626^{\mathrm{T}}$, are presented in Supplementary Table S1 in IJSEM Online. Strain LU14 ${ }^{\mathrm{T}}$ differed from $K$. sandramycini DSM $15626^{\mathrm{T}}$ mainly in the presence of

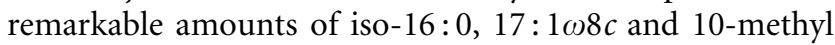
branched fatty acids. The phospholipids found in strain LU14 ${ }^{\mathrm{T}}$ were diphosphatidylglycerol, phosphatidylglycerol, phosphatidylcholine and phosphatidylinositol, which correspond to phospholipid type III according to Lechevalier et al. (1977).

Various differentiating physiological characteristics between strain $\mathrm{LU} 14^{\mathrm{T}}$ and other Kribbella type strains are shown in

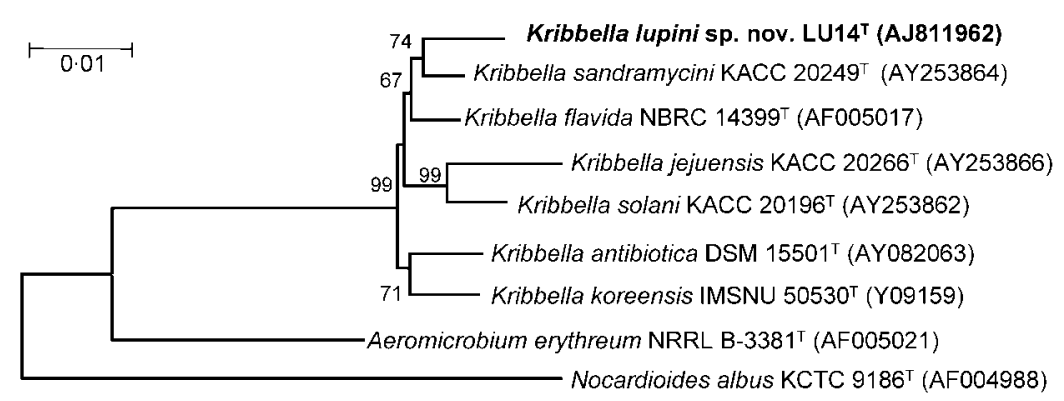

Fig. 1. Phylogenetic tree showing the relationship between members of the genus Kribbella and the novel isolate LU14 $4^{\top}$ based on 16S rRNA gene sequences. The tree was constructed by neighbour-joining analysis with distances based on the Kimura twoparameter model. Bootstrap values (1000 replicates) are shown as percentages at each node for values above $50 \%$. GenBank accession numbers are given in parentheses. Bar, 1 substitution per 100 nucleotides. 
Table 1. Characteristics that differentiate isolate $\mathrm{LU} 14^{\top}$ and other Kribbella species

Strains: 1, LU14 ${ }^{\mathrm{T}}$; 2, K. sandramycini DSM $15626^{\mathrm{T}}$; 3, K. flavida KACC $20248^{\mathrm{T}}$; 4, K. koreensis KACC $20250^{\mathrm{T}}$; 5, K. antibiotica DSM $15501^{\mathrm{T}}$; 6, K. jejuensis KACC $20266^{\mathrm{T}}$; 7, K. solani KACC $20196^{\mathrm{T}}$. Data for K. jejuensis and K. solani were taken from Song et al. (2004). +, Positive; -, negative; ND, not determined; W, weak reaction. The contradictory results obtained by Park et al. (1999) and Lee et al. (2000) are shown in parentheses.

\begin{tabular}{|c|c|c|c|c|c|c|c|}
\hline Characteristic & 1 & 2 & 3 & 4 & 5 & 6 & 7 \\
\hline \multicolumn{8}{|l|}{ Enzyme activities: } \\
\hline Casein hydrolysis & + & + & + & + & + & $\mathrm{W}$ & - \\
\hline Cystine arylamidase & $\mathrm{w}$ & + & + & + & $\mathrm{ND}$ & $\mathrm{ND}$ & $\mathrm{ND}$ \\
\hline Esterase (C4) & - & + & + & + & $\mathrm{ND}$ & $\mathrm{ND}$ & $\mathrm{ND}$ \\
\hline$\beta$-Galactosidase & $\mathrm{w}$ & + & + & + & $\mathrm{ND}$ & $\mathrm{ND}$ & ND \\
\hline Naphthol-AS-BI-phosphohydrolase & - & + & + & - & $\mathrm{ND}$ & $\mathrm{ND}$ & ND \\
\hline Nitrate reduction & - & - & + & - & - & - & - \\
\hline Oxidase & + & + & + & - & + & $\mathrm{ND}$ & $\mathrm{ND}$ \\
\hline Pyrrolidonyl arylamidase & - & + & + & + & $\mathrm{ND}$ & $\mathrm{ND}$ & ND \\
\hline Starch hydrolysis & - & $\mathrm{w}$ & - & + & + & - & - \\
\hline Urease & - & + & + & + & $\mathrm{ND}$ & - & + \\
\hline \multicolumn{8}{|l|}{ Carbon sources: } \\
\hline L-Arabinose & + & $\mathrm{w}$ & - & + & + & + & + \\
\hline D-Galactose & + & + & - & + & + & + & - \\
\hline D-Maltose & - & + & + & $\mathrm{ND}$ & + & $\mathrm{ND}$ & $\mathrm{ND}$ \\
\hline D-Mannose & + & + & - & + & + & - & + \\
\hline D-Melezitose & - & + & + & + & $\mathrm{ND}$ & + & + \\
\hline L-Rhamnose & + & + & - & + & + & + & + \\
\hline D-Sorbitol & + & - & - & $\mathrm{ND}$ & + & $\mathrm{ND}$ & ND \\
\hline \multicolumn{8}{|l|}{ Growth in/at: } \\
\hline $12^{\circ} \mathrm{C}$ & + & - & + & + & - & $\mathrm{ND}$ & ND \\
\hline $37^{\circ} \mathrm{C}$ & + & $-(+)$ & $-(+)$ & $-(+)$ & - & + & - \\
\hline $\mathrm{pH} 5 \cdot 0$ & - & + & $-(+)$ & - & - & - & - \\
\hline $\mathrm{pH} 9 \cdot 0$ & + & + & + & + & - & - & - \\
\hline $3 \% \mathrm{NaCl}$ & + & + & + & - & - & $\mathrm{ND}$ & ND \\
\hline $5 \% \mathrm{NaCl}$ & + & - & - & - & - & $\mathrm{ND}$ & $\mathrm{ND}$ \\
\hline $7 \% \mathrm{NaCl}$ & + & - & - & - & - & $\mathrm{ND}$ & ND \\
\hline
\end{tabular}

Table 1 . The ability of strain $\mathrm{LU} 14^{\mathrm{T}}$ to tolerate $7 \% \mathrm{NaCl}$ deserves special mention, as the remaining species do not tolerate $\mathrm{NaCl}$ concentrations above $3 \%$. It should also be noted that, in the original and emended descriptions of the genus Kribbella (Park et al., 1999; Sohn et al., 2003), production of urease and oxidase are reported as characteristic of the genus, but as more species have been described, the results for these properties seem to vary. The novel isolate showed resistance to ampicillin $(2 \mu \mathrm{g})$, penicillin $\mathrm{G}(10 \mathrm{U})$ and rifampicin $(2 \mu \mathrm{g})$ after 7 days of incubation and was susceptible to amoxycillin $(30 \mu \mathrm{g})$, gentamicin $(10 \mu \mathrm{g})$, neomycin $(5 \mu \mathrm{g})$, novobiocin $(5 \mu \mathrm{g})$, oxytetracycline $(30 \mu \mathrm{g})$, streptomycin $(300 \mu \mathrm{g})$, tobramycin $(10 \mu \mathrm{g})$, vancomycin $(30 \mu \mathrm{g})$ and tetracycline $(30 \mu \mathrm{g})$. Other results for the novel isolate are given in the species description.

DNA-DNA hybridization experiments revealed a low level of relatedness $(38.5 \%)$ between isolate $\mathrm{LU}_{14}^{\mathrm{T}}$ and $\mathrm{K}$. sandramycini DSM $15626^{\mathrm{T}}$. Given the low DNA-DNA hybridization value obtained for these two strains, further tests were not performed between isolate $\mathrm{LU} 14^{\mathrm{T}}$ and $K$. flavida NBRC $14399^{\mathrm{T}}$, which shared a $16 \mathrm{~S}$ rRNA gene sequence similarity slightly lower than $\mathrm{LU}_{14} 4^{\mathrm{T}}$ and $K$. sandramycini KACC $20249^{\mathrm{T}}$. In the case of K. sandramycini KACC $20249^{\mathrm{T}}$ and K. flavida NBRC $14399^{\mathrm{T}}$, which share the highest $16 \mathrm{~S}$ rRNA gene sequence similarity $(98.9 \%)$ between all of the recognized Kribbella species, the DNADNA reassociation value was $43 \%$ (Park et al., 1999). Various authors have reported that certain genera, including actinomycetes (Wink et al., 2003), show less than $70 \%$ DNA-DNA reassociation values at sequence similarities higher than $98.5 \%$, enabling this correlation between genomic and gene sequence similarities to be used to delineate novel species provided that DNA-DNA reassociation data exist for most of the other species (Romanenko et al., 2004). This indeed, appears to be the case for the presently described species of the genus Kribbella. Based on the overall results, we propose that strain $\mathrm{LU} 14^{\mathrm{T}}$ represents a novel species, Kribbella lupini sp. nov. 


\section{Description of Kribbella lupini sp. nov.}

Kribbella lupini (lu'pin.i. L. gen. n. lupini of lupin, isolated from Lupinus angustifolius).

Gram-positive, non-acid-fast, strictly aerobic actinomycete. Colonies are white to cream, irregular and show lichenous shapes. Well-developed substrate mycelium with hyphae that branch extensively and fragment into coccoid to rod elements. Abundant white aerial mycelium is produced that fragments into rod-shaped elements. No diffusible pigments observed. Grows between 12 and $37^{\circ} \mathrm{C}$, with an optimum temperature of $28^{\circ} \mathrm{C}$. Grows between $\mathrm{pH}$ 6-9. Grows in the presence of $7 \% \mathrm{NaCl}$. Catalase and oxidase are produced. Arbutin, aesculin, casein and gelatin are degraded, but not starch, urea or xylan. Acid is produced from glucose. The following substrates are used as carbon sources: adipate, L-alanine, L-arabinose, L-arginine, D-cellobiose, D-galactose, gluconate, D-glucose, L-histidine, L-lysine, malate, maltose, D-mannitol, D-mannose, D-melibiose, $\mathrm{N}$ acetylglucosamine, L-proline, D-raffinose, L-rhamnose, Dsorbitol, L-sorbose, sucrose, D-trehalose, L-tyrosine, xylitol and DL-valine. Caprate, citrate, D-melezitose and L-serine are not used as carbon sources. Production of arginine dihydrolase, alkaline phosphatase, esterase lipase (weak), lipase (C14), leucine arylamidase, valine arylamidase, cystine arylamidase, trypsin, $\alpha$-chymotrypsin, acid phosphatase, $\alpha$-galactosidase, $\beta$-galactosidase, $\alpha$-glucosidase, $\beta$ glucosidase, $N$-acetyl- $\beta$-glucosaminidase, $\alpha$-mannosidase and $\alpha$-fucosidase. Does not produce esterase (C4), naphthol-AS-BI phosphohydrolase or $\beta$-glucuronidase. Cell wall contains LL-Dpm. Major fatty acids are anteiso$15: 0(28 \%)$ and iso- $16: 0(21 \%)$. The DNA G + C content is $68 \mathrm{~mol} \%$.

The type strain, $\mathrm{LU} 14^{\mathrm{T}}\left(=\mathrm{DSM} 16683^{\mathrm{T}}=\mathrm{LMG} 22957^{\mathrm{T}}\right)$, was isolated from root nodules of Lupinus angustifolius.

\section{Acknowledgements}

We would like to thank Dr B. J. Tindall for his valuable help with naming the species. We thank the DSMZ staff for their technical assistance. This work was supported by the Ministerio de Ciencia y Tecnología (Spain) and the Junta de Castilla y León (Comunidad de Castilla y León, Spain).

\section{References}

Cashion, P., Holder-Franklin, M. A., McCully, J. \& Franklin, M. (1977). A rapid method for the base ratio determination of bacterial DNA. Anal Biochem 81, 461-466.

De Ley, J., Cattoir, H. \& Reynaerts, A. (1970). The quantitative measurement of DNA hybridization from renaturation rates. Eur J Biochem 12, 133-142.

Doetsch, R. N. (1981). Determinative methods of light microscopy. In Manual of Methods for General Bacteriology, pp. 21-33. Edited by P. Gerhardt, R. G. E. Murray, R. N. Costilow, E. W. Nester, W. A. Wood, N. R. Krieg \& G. H. Phillips. Washington, DC: American Society for Microbiology.
Fitch, W. M. (1971). Towards defining the course of evolution: minimum change for a specific tree topology. Syst Zool 20, 406-416.

Huß, V. A. R., Festl, H. \& Schleifer, K. H. (1983). Studies on the spectrophotometric determination of DNA hybridization from renaturation rates. Syst Appl Microbiol 4, 184-192.

Kumar, S., Tamura, K., Jakobsen, I. B. \& Nei, M. (2001). MEGA2 molecular evolutionary genetics analysis software. Bioinformatics $\mathbf{1 7}$, 1244-1245.

Lechevalier, M. P., De Bièvre, C. \& Lechevalier, H. (1977). Chemotaxonomy of aerobic actinomycetes: phospholipid composition. Biochem Syst Ecol 5, 249-260.

Lee, S. D., Kang, S. O. \& Hah, Y. C. (2000). Hongia gen. nov., a new genus of the order Actinomycetales. Int J Syst Evol Microbiol 50, 191-199.

Li, W.-J., Wang, D., Zhang, Y.-Q., Schumann, P., Stackebrandt, E., Xu, L.-H. \& Jiang, C.-L. (2004). Kribbella antibiotica sp. nov., a novel nocardioform actinomycete strain isolated from soil in Yunnan, China. Syst Appl Microbiol 27, 160-165.

Mandel, M. \& Marmur, J. (1968). Use of ultraviolet absorbancetemperature profile for determining the guanine plus cytosine content of DNA. Methods Enzymol 12B, 195-206.

Minnikin, D. E., O'Donnell, A. G., Goodfellow, M., Alderson, G., Athalye, M., Schaal, K. \& Parlett, J. H. (1984). An integrated procedure for the extraction of bacterial isoprenoid quinones and polar lipids. J Microbiol Methods 2, 233-241.

Park, Y.-H., Yoon, J.-H., Shin, Y. K., Suzuki, K., Kudo, T., Seino, A., Kim, H.-J., Lee, J. S. \& Lee, S. T. (1999). Classification of 'Nocardioides fulvus' IFO 14399 and Nocardioides sp. ATCC 39419 in Kribbella gen nov., as Kribbella flavida sp. nov. and Kribbella sandramycini sp. nov. Int J Syst Bacteriol 49, 743-752.

Rivas, R., Sánchez, M., Trujillo, M. E., Zurdo-Piñeiro, J. L., Mateos, P. F., Martínez-Molina, E. \& Velázquez, E. (2003). Xylanimonas cellulosilytica gen. nov., sp. nov., a xylanolytic bacterium isolated from a decayed tree (Ulmus nigra). Int J Syst Evol Microbiol 53, 99-103.

Romanenko, L. A., Lysenko, A. M., Rohde, M., Mikhailov, V. V. \& Stackebrandt, E. (2004). Psychrobacter maritimus sp. nov. and Psychrobacter arenosus sp. nov., isolated from coastal sea ice and sediments of the Sea of Japan. Int J Syst Evol Microbiol 54, 1741-1745.

Saitou, N. \& Nei, M. (1987). The neighbor-joining method: a new method for reconstructing phylogenetic trees. Mol Biol Evol 4, 406-425.

Schleifer, K. H. (1985). Analysis of the chemical composition and primary structure of murein. Methods Microbiol 18, 123-156.

Schleifer, K. H. \& Kandler, O. (1972). Peptidoglycan types of bacterial cell walls and their taxonomic implications. Bacteriol Rev 36, 407-477.

Schröder, K. H., Naumann, L., Kroppenstedt, R. M. \& Reischl, U. (1997). Mycobacterium hassiacum sp. nov., a new rapidly growing thermophilic mycobacterium. Int J Syst Bacteriol 47, 86-91.

Shirling, E. B. \& Gottlieb, D. (1966). Methods for characterization of Streptomyces species. Int J Syst Bacteriol 16, 313-340.

Sohn, K., Hong, S. G., Bae, K. S. \& Chun, J. (2003). Transfer of Hongia koreensis Lee et al. 2000 to the genus Kribbella Park et al. 1999 as Kribbella koreensis comb. nov. Int J Syst Evol Microbiol 53, 1005-1007.

Song, J., Kim, B.-Y., Hong, S.-B., Cho, H.-S., Sohn, K., Chun, J. \& Suh, J.-W. (2004). Kribbella solani sp. nov. and Kribbella jejuensis sp. nov., isolated from potato tuber and soil in Jeju, Korea. Int J Syst Evol Microbiol 54, 1345-1348.

Staneck, J. L. \& Roberts, G. D. (1974). Simplified approach to the identification of aerobic actinomycetes by thin layer chromatography. Appl Microbiol 28, 226-231. 
Thompson, J. D., Gibson, T. J., Plewniak, F., Jeanmougin, F. \& Higgins, D. G. (1997). The CLUSTAL_X windows interface: flexible strategies for multiple sequence alignment aided by quality analysis tools. Nucleic Acid Res 25, 4876-4882.

Trujillo, M. E., Fernández-Molinero, C., Velázquez, E., Kroppenstedt, R. M., Schumann, P., Mateos, P. F. \& Martínez-Molina, E. (2005). Micromonospora mirobrigensis sp. nov. Int J Syst Evol Microbiol 55, 877-880.

Vincent, J. M. (1970). The cultivation, isolation and maintenance of rhizobia. In A Manual for the Practical Study of the Root-Nodule Bacteria, pp. 1-13. Edited by J. M. Vincent. Oxford: Blackwell Scientific Publications.
Williams, S. T., Goodfellow, M., Alderson, G., Wellington, E. M. H., Sneath, P. H. A. \& Sackin, M. J. (1983). Numerical classification of Streptomyces and related genera. J Gen Microbiol 129, 1743-1813.

Wink, J. M., Kroppenstedt, R. M., Ganguli, B. N., Nadkarni, S. R., Schumann, P., Seibert, G. \& Stackebrandt, E. (2003). Three new antibiotic producing species of the genus Amycolatopsis, Amycolatopsis balhimycina sp. nov., A. tolypomycina sp. nov., A. vancoresmycina sp. nov., and description of Amycolatopsis keratiniphila subsp. keratiniphila subsp. nov. and A. keratiniphila subsp. nogabecina subsp. nov. Syst Appl Microbiol 26, 38-46. 